\title{
DISPUTE RESOLUTION OF INHERITANCE DISTRIBUTION FOR THE SUBSTITUTE HEIR IN TERMS OF ISLAMIC LAW
}

\author{
By :
}

Putri Larasati, M. Darudin, Sirman Dahwal

\begin{abstract}
This study was aimed to determine the settlement of disputes regarding the distribution of inheritance to substitute heirs left by their grandparents in terms of Islamic law and to determine the position of substitute heirs for the assets according to Al-Quran and Hadith provisions. The data collection technique used in this study was a normative legal research methodology based on a literature study. From this research, it is known that (a) The rights of grandchildren as substitute heirs to replace their deceased parents are the same as the rights which obtained by their mother's sister. It caused by the 2 sons and 3 daughters so that the distribution of inheritance is based on a ratio of 2:1. In accordance with the provisions of Q.S An-Nisaa'/7:4. To give the inheritance to a grandchild who replaces their deceased parents' position, he/she can use a mandatory will so that he/she can receive the inheritance left by their grandparents. And if there is a dispute regarding the distribution of inheritance to the replacement heirs, it should be resolved by a mediation process as a tools of dispute resolution because it is considered as faster, easier, and less costly than the litigation process, (b) Al-Quran does not regulate the provisions regarding substitute heirs, but the Article 185 of the Islamic Law Compilation stipulates that the substitute heirs can replace their parents and the asset share of substitute heirs,must not exceed the share of the heirs which is equal to was replaced.
\end{abstract}

Keywords: Conflict Resolution, Distribution of the Inheritance, Successor Heir, Islamic of Law 


\section{A. INTRODUCTION}

\section{Research Background}

Islamic Inheritance

Law regulates the asset transfer from a deceased person to a living person. This rule regarding the transfer of assetsis called by various names. In Islamic law literature, several terms of naming are found to Islamic inheritance law, such as Faraid, Fikih Mawaris, and Hukm al-Waris. This difference in naming occurs because of the difference in the direction which is the main point in the discussion. The common word that used wasFaraid. This word was used by An-Nawawi in the Minhaj al-Thalibin book. ${ }^{1}$

The basis and main source of Islamic law are the Qur'an. Some of the verses in the Qur'an that directly regulate Islamic inheritance are as follows:

a. Qs an-Nisaa '/ 4: 7
${ }^{1}$ Amir Syarifuddin, Hukum Kewarisan Islam, PT AdhityaAndrebina Agung, Jakarta, 2004, p. 5.

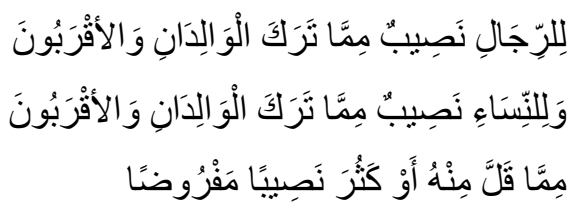

This means more or less:

"For men is a share of what the parents and close relatives leave, and for women is a share of what the parents and close relatives leave, be it little or much - an obligatory share,"2

Inheritance according to Islamic law, namely, several assets and all rights of the deceased who are clean. That is, the inheritance inherited by the heirs is several assets and all rights, after being spent for burial, paying the debts of the heirs, and carrying out or paying wills. $^{3}$

The Qur'an does not directly mention the child of the child in its verses to inherit the grandchildren. It can be seen that there have

\footnotetext{
${ }^{2}$ Web Translate of Surat An-Nisa Verse 7, accessed on January 28, 2020 from https://tafsirweb.com/1540-surat-an-nisa-ayat-7.html

${ }^{3}$ WirjonoProdjodikoro, Hukum Warisan di Indonesia, Sumur Bandung, Bandung, 1991, p. 8
} 
been many cases regarding the distribution of inheritance in Indonesia. The case of distribution of inheritance occurred in Bengkulu City to $\mathrm{HM}$ and AZ families. The husband and wife couple HM and $\mathrm{AZ}$ are known to have married in 1974 and have 6 children, namely 4 girls and 2 boys. $\mathrm{DH}$ is the first daughter in the family. In 1997, DH married to AP and had 3 children, namely AJP, AP, and AP. Her second child is a boy named $\mathrm{DN}$. $\mathrm{SH}$ is the name of his wife,they married in 2003 and $\mathrm{FN}$ is the son of this marriage. Another boy is the third child named DCA. DCA has 2 children, namely DA and KA from AP whom she has married since 2005 . The fourth child of HM and AZ is a girl named DYS. DI married to DYS in 2007 and is blessed with a child, namely VST. The fifth child, DHJ, was married to $\mathrm{RJ}$ in 2018 and has no children. Meanwhile, her youngest daughter is not married.

However, in 2013, DYS who was the fourth child of HM and AZ's family died. Then followed by AZ who died in 2015. Then HM died in 2019. In this case, HM and AZleft a house in Mukomuko Regency which sold forRp. 300.000.000,- (three hundred million rupiahs), a house in Bengkulu City which sold forRp. 600.000.000,- (six hundred million rupiahs), and a savings of Rp. 250,000,000.- (two hundred and fifty million rupiahs).So that the total inheritance left by $\mathrm{HM}$ and $\mathrm{AZ}$ is $\mathrm{Rp}$. 1,150,000,000, - (one billion one hundred and fifty million rupiahs).

Because $\mathrm{HM}$ and $\mathrm{AZ}$ have passed away, it can be concluded that their five children are the heirs of the assets owned by both parents. It is known that HM-AZ has six children, but DYS, as the fourth child is not included in the category of heirs because the requirements to become an heir,is someone who is still alive and DYS has died in 2013. However, DYS left a child named VST. VST is known to be 10 years old and 
still in school. So VST requires quite a lot of cost, especially for education. The VST position in this family is the grandson of $\mathrm{HM}$ and $\mathrm{AZ}$, but he is not an heir. In this case, VST can be said to be a substitute heir from his mother, namely DYS. However, based on Islamic Inheritance Law, there are no rules governing grandchildren as heirs. Therefore, if he does not get the inheritance from his grandparents, it is seen from the Theory of Rights and Theory of Justice that it is considered unfair considering that the child still needs money for his life. However, if the inheritance case above is related to the Theory of Rights, which means that rights are something inherent in humans or the Theory of Justice where VST does not get the inheritance of their grandparents, which is very unfair to VST because they are has rights inherited from his deceased mother.

\section{Identification of problems}

Based on the
background above, the
problems are:
1. How is the settlement of
disputes regarding the
distribution of inheritance
for grandchildren as a
substitute heirsin terms of
Islamic law?
2. How is the position of
grandchildren
substitute heirsto the
assets left by their
grandparents in terms of
Islamic law?

\section{B. RESEARCH METHODS}

This type of research used by the author is descriptive research. Descriptive research aims to describe accurately the characteristics of an individual, condition, symptom or group, or to determine the spread of a symptom, or to determine whether there is a relationship between a symptom and other symptoms in society. The author examines the settlement of disputes regarding the distribution of inheritance to the replacement heirs for the assets left by their grandparents in terms of Islamic law.

\section{RESULTS AND DISCUSSION}




\section{Dispute Settlement of the Distribution of Inheritance for Grandchildren as a}

Substitute Heirs in Terms of Islamic Law

Table 2. The Wealth Received by the Heirs and

Calculation of the Distribution of Inheritance According to Islamic Law

2.

\begin{tabular}{|l|c|c|}
\hline \multicolumn{1}{|c|}{ Heirs } & Share Received by the Heir & $\begin{array}{c}\text { Calculation of the } \\
\text { distribution of inheritance } \\
\text { according to Islamic law }\end{array}$ \\
\hline DH & $1 / 6$ & $1 / 8$ \\
\hline DN & $1 / 8$ & $2 / 8$ \\
\hline DC & $1 / 5$ & $2 / 8$ \\
\hline VST & $1 / 23$ & $1 / 8$ \\
\hline DH & $1 / 5$ & $1 / 8$ \\
\hline DZ & $1 / 5$ & $1 / 8$ \\
\hline
\end{tabular}

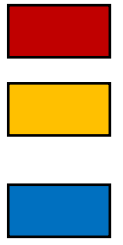

Daughter

Son

Grandchild

Based on the results of the interview with $\mathrm{DH}^{4}$, the inheritance in the form of savings of Rp. 250,000,000,- (two hundred and fifty million rupiahs), a house in Bengkulu City which has been sold for Rp. 600,000,000,- (six hundred million rupiahs) and a house in Muko-muko which has been sold for Rp. 300,000,000,- (three hundred million rupiahs) so that the total inheritance from HM and AZ is Rp. 1,150,000,000,(one billion one hundred and fifty million rupiahs).

\footnotetext{
${ }^{4}$ The interview with the heir of HM and AZ
} on Wednesday 08 September 2020.
The inheritance is distributed according to the needs of each heir. DH is a daughter who gets $1 / 5$ of the portion or Rp. 200,000,000,(two hundred million rupiahs), $\mathrm{DN}$ is a son who gets $1 / 8$ of the portionor Rp.150,000,000,- (one hundred and fifty million rupiahs), DC is a son who gets $1 / 5$ of the portionor Rp.250,000,000,- (two hundred and fifty thousand rupiahs) because DC has a baby so that he has a lot of needs, DH who is a daughter gets $1 / 5$ of the portion or Rp.250,000,000,- (two hundred and fifty thousand 
rupiahs) because the money is used for her childbirth preparation, DZ who is a daughter gets $1 / 5$ of the portionor Rp.250,000,000,- (two hundred and fifty million rupiahs) whose the money will be used for wedding preparation, while VST, who is the grandchild of HM and $A Z$, gets $1 / 23$ of the portionor Rp. 50,000,000,- (fifty million rupiahs).

According to the author, in order to distribute the inheritance to the heirs fairly, it should be adjusted to what has been determined in the $\mathrm{Al}$ Qur'an. DH, DN, DC, DH and DZ are a group of heirs of Son (AL) Daughter (AP)
$: 2$ with a ratio of 2 $: 4$ with a ratio of 1 dzawilfurudh, which receive a portion that has been determined for a certain size. From table 2 above, it can be concluded that the rights for male heirs are $2 / 8$ of the portion, for the daughter heirs $1 / 8$ of the portionand the granddaughter who replaces the position of the mother gets $1 / 8$ of the portion. Since there are 2 sons and 3 daughters and 1 grandchild as substitute heirs to replace the mother's position, the distribution of inheritance is based on a 2:1 division, 2 parts for sons and 1 part for daughters. Inheritance: Rp. 1,150,000,000,(one billion one hundred and fifty million rupiah)

$$
\begin{aligned}
& =4 \\
& =4 \quad+ \\
& =8
\end{aligned}
$$

So, for AL section is $2 / 8$ of the portion, while AP is $1 / 8$ of the portion.

$\begin{array}{lll}\text { DH (AP) } & =1 / 8 \times \text { Rp. } 1.150 .000 .000 & =\text { Rp. } 143.750 .000,- \\ \text { DN (AL) } & =2 / 8 \times \text { Rp. } 1.150 .000 .000 & =\text { Rp. } 287.500 .000,- \\ \text { DC (AL) } & =2 / 8 \times \text { Rp. } 1.150 .000 .000 & =\text { Rp. } 287.500 .000,- \\ \text { VST (cucu) } & =1 / 8 \times \text { Rp. } 1.150 .000 .000=\text { Rp. } 143.750 .000,- \\ \text { DH (AP) } & =1 / 8 \times \text { Rp. } 1.150 .000 .000=\text { Rp. } 143.750 .000,- \\ \text { DZ (AP) } & =1 / 8 \times \text { Rp. } 1.150 .000 .000 & =\text { Rp. } 143.750 .000,-\end{array}$

Rp. 1.150.000.000,- 
If the heir counts by using 2:1 ratio for the distribution of inheritance assets, then it is obtained for the daughter is $1 / 8$ of the portion or the equivalent of Rp. 143,750,000, - (one hundred forty-three million seven hundred and fifty thousand rupiahs), it includes for VST who are the grandchild of $\mathrm{HM}$ and $\mathrm{AZ}$ who replaced their deceased mother, while the distribution for the sons was $2 / 8$ of the portionor equivalent to $\mathrm{Rp}$. 287,500,000, - (two hundred eighty-seven million five hundred thousand rupiahs). The calculation is in accordance with what Allah SWT ordered in Surah AnNisaa 'in verse 11, which means more or less:

"Allah requires for you about (the distribution of inheritance for your children, that is, the portion of a son is equal to that of two daughters ..."

And also in accordance with Article 176
Compilation of Islamic Law

(KHI) which states:

"Daughters if only one person gets a portion, if two or more people together get two-thirds of the portion, and if daughters are together with sons, then the distribution for sons is two to one with daughters."

With this fair distribution, the portion received by VST is as a substitute heir, not because of his status as an heir who has a direct relationship with the heir, but solely because of the property received, was originally the portion received by his mother.

According to the author, so that grandchildren can receive an inheritance because they replace the position of their deceased parents, it is better to make a mandatory will. Mandatory will first appeared in Egypt as the Legacy Law of 1946 to counter the view that grandchildren are amazed by sons. ${ }^{5}$ In the Egyptian will 
law, the wills is limited to the heir's grandchildren whose parents have passed away earlier and they do not get a share of the inheritance due to their position as dzawil arham or being veiled by another heir. ${ }^{6} \mathrm{~A}$ mandatory will can be interpreted as an obligatory gift to a grandchild who is prevented from receiving an inheritance because his mother or father died before his grandfather or grandmother died. Grandchildren cannot get the inheritance if they are with sons and the position of the grandchildren is as dzawil arham. So that the grandchildren can get the inheritance from their grandparents, then the mandatory will is taken. ${ }^{7}$ Or if

Kompilasi Hukum Islam (KHI) Dalam Kajian Normatif Yuridis, Muslim Heritage, Vol. 1, No. 2, 2016, p. 45.

${ }^{6}$ Ahmad Zahari, Tiga Versi Hukum Kewarisan Islam, Syafi'i, Hazairin dan KHI, Romeo Grafika, Pontianak, 2006, hlm. 98, quoted from Eko Setiawan, Penerapan Wasiat Wajibah Menurut Kompilasi Hukum Islam (KHI) Dalam Kajian Normatif Yuridis, Muslim Heritage, Vol. 1, No. 2, 2016, p. 45.

${ }^{7}$ Anshary, Hukum Waris Islam Dalam Teori dan Praktik, Pustaka Belajar, Yogyakarta, 2013, p. 87, quote from Eko Setiawan, Penerapan Wasiat Wajibah Menurut Kompilasi Hukum Islam (KHI) Dalam Kajian Normatif Yuridis, Muslim Heritage, Vol. 1, No. 2, 2016, p. 45. the heir does not or has not made a compulsory will, so that the grandchildren can replace the position of their deceased parents can be reached through mediation. This is so that the grandchildren can get inherited assets fairly and in accordance with Islamic law. There are 2 types of mediation, namely:

\section{a. Mediation in Islamic Law}

\section{Concepts}

Tahkimis a form of legal settlement outside the line of formal justice by means of appointing a hakam/muhakkam, outside the criminal law. Tahkim has a lower position than the court because the decisions resulted from this tahkim only bind the parties who filed and only on the disputed issues.

The legal basis for the law contained in the Qur'an is found in the letter Al-Hujurat verse 9 which means more or less:

"And if two factions among the believers should fight, then 


\begin{abstract}
make settlement between the two. But if one of them oppresses the other, then fight against the one that oppresses until it returns to the ordinance of Allah. And if it returns, then make settlement between them in justice and act justly. Indeed, Allah loves those who act justly." ${ }^{8}$
\end{abstract}

The above verse explains that carrying out peace efforts between warring parties is obligatory.

The main elements of tahkîmare the disputing parties, the parties' agreement to avoid the judiciary in resolving disputes, and the agreement to resolve them through tahkîm, hakam (mediator) who mediates between the parties in resolving their disputes, and the dispute itself. ${ }^{9}$ Each element must meet the requirements so that the tahkim can be carried out and have legal force. Decisions that are born from the tahkîm forum will have the legal force to be executed if they meet four conditions:

1. TheHakam is a person who has the ability of ijtihad or controls the source of the dispute in all its aspects. If this condition is not fulfilled the decision will be null and void;

2. The existence of hakammust be agreed upon by the parties voluntarily, this willingness must continue until the decision-making process;

3. The case in dispute is a particular case. In this regard, cases that can be judged are material rights, exchange agreements, and cases that can be carried out are 'afw and

\footnotetext{
${ }^{8}$ Translate of Web, Surat Al-Hujurat Verse 9, accessed on 5 June 2020 from:https://tafsirq.com/49-al-hujurat/ayat-9
}

${ }^{9}$ Husain Musa Raghib, Mausu'ah Al-Iqtishad al-Islami fil-Masharif wan-Nuqud wal-Aswaq alMaliyah, Daras-Salam, Cairo, 2009, p. 344. 
ibrâ'.Some cases cannot be convicted, namely cases which in particular can only be decided by (formal court judges) by force;

4. Terms related to whether or not the decision-Hakam binding for the parties.

Mediation in Islamic law has been formulated in the concept of tahkim. This proves the conformity of Islamic law with the needs of modern humanitarian law. Even though the concept of tahkîm is a non-formal institution, but its legal force remains to bind between the two parties and also the decision is voluntary, so that if one of the disputing parties is objects, the decision is brought to the formal justice institution.

b. Mediation in Courts (Based on Supreme Court Regulation No.1 of 2016 concerning Mediation Procedures in Courts)

Based on Article 4 of

Law no. 48 of 2009 concerning Judicial Power states "Courts help justice seekers and try to overcome all obstacles and obstacles to achieve a simple, fast, and low-cost trial. There are many advantages to completing a case in court because every decision made by a judge cannot be contested, is open and adjudicates all cases, both civil and criminal, but if viewed from the weaknesses, resolving cases to court uses a relatively large and more expensive fee, the dispute resolution process is very long, it can take years to resolve, due to legal efforts for appeal, cassation, and reconsideration $(P K)$.

The process of resolving disputes through the litigation (court) process tends to generate new problems because it is a win-lose nature, the settlement of disputes outside the court is seen as a more fast and efficient process of proceedings. This out of court dispute resolution process is called alternative dispute resolution. Alternative dispute resolution develops in the 
background because it is to reduce congestion in the courts. Mediation is an alternative dispute resolution that is seen as resolving disputes with the aim of a win-win solution.

Mediation is a method of resolving disputes through the negotiation process to obtain agreement from the parties with the assistance of a mediator. Mediation, when described contains the following elements:

a) Mediation is a process of dispute resolution based on voluntary principles through a negotiation;

b) The mediator involved is tasked with assisting the disputing parties to find a solution;

c) The mediator involved must be accepted by the disputing parties;

d) The mediator may not authorize the decisions during the negotiations;

e) The purpose of mediation is to reach or produce acceptable conclusions from the disputing parties. ${ }^{10}$

Mediation is an intermediary procedure where someone acts as an intermediary to communicate between the disputing parties so that their different views on the dispute can be understood and it is possible to be reconciled. Mediation that creates a peace agreement will be a complete solution because the final result does not use the win or lose principle. The settlement with the mediation process provides many benefits for the parties the time taken will reduce costs to be cheaper, from an emotional point of view, resolution by mediation can provide comfort for the parties because the points of the agreement are made by the parties themselves according to their wishes. Meditation has been around for a long time because the community dispute settlement

\footnotetext{
${ }^{10}$ GunawanWidjaja, AlternatifPenyelesaianSengketa, PT Raja Grafindo Persada, Jakarta, 2002, p. 59.
} 
system generally uses the principle of mediation

\section{The Position of Grandchildren} as Substitute Heirs to the Assets Left by Grandparents in terms of Islamic Law

In this case, it was explained that based on Islamic Inheritance Law, it does not regulate the granddaughter of a daughter as a substitute heirs But the Islamic Law Compilation introduces a system of replacement inheritance in Article $185:^{11}$

a. The heirs who die earlier than the heirs can be replaced by their children, except for those who are mentioned in Article 173.

b. The share of the replacement heir must not exceed the share of the heir which is equivalent to the one who was replaced. According to the writer of the above provisions, it is explained that VST, who is a daughter of DYS, can become a substitute inheritheirs but its share must not exceed the share

\footnotetext{
${ }^{11}$ Ahmad Rofiq, Hukum Perdata Islam di Indonesia EdisiRevisi, PT Raja Grafindo Persada, Jakarta, 2015, p. 331.
}

of the heirs which is equal to those replaced by him.

\section{CLOSING}

\section{Conclusion}

a. Provisions for substitute heirsand the number of rights received are not specified in the Qur'an and Hadith. In Indonesia, it is regulated in the Compilation of Islamic Law, Article 185. Compilation of Islamic Law is the result of ijtihad scholars who state that:

(1) The heirs who die earlier than the heirs can be replaced by their children

(2) The share of the replacement heir must not exceed the share of the heir which is equivalent to the one who was replaced.

b. Al-Qur'an and Article 176 Compilation of Islamic Law (KHI) states regarding the distribution of inheritance for sons and daughters in ratio 2: 1. So that the equitable distribution of male heirs gets $2 / 8$ of the inheritance, while female heirs get $1 / 8$ of the 
inheritance. So, VST who is a substitute heir who replaces the position of his mother gets $1 / 8$ of the inheritance in accordance with Article 185 paragraph (2) of the KHI. Or for the heirs who do not know about the distribution according to Islamic law, they should solve it through mediation based on Islamic concepts or mediation in court so that the heirs get their rights fairly.

\section{Suggestions}

In order to the heirs, especially the successor heirs, can get their rights fairly, the Compilation of Islamic Law which acknowledges the position of a replacement heir will be fully legalized because this provision is not contained in the Al-Qur'an. So that the replacement heirs still get their rights fairly.

\section{REFERENCES}

Ahmad Rofiq, Hukum Perdata Islam di Indonesia EdisiRevisi, PT Raja Grafindo Persada, Jakarta, 2015.

Ahmad Zahari, Tiga Versi Hukum Kewarisan Islam, Syafi'i, Hazairin dan KHI, Romeo Grafika, Pontianak, 2006, quoted from Eko Setiawan, Penerapan Wasiat Wajibah Menurut Kompilasi Hukum Islam (KHI) Dalam Kajian Normatif Yuridis, Muslim Heritage, Vol. 1, No. 2, 2016.
Amir Syarifuddin, Hukum Kewarisan Islam, PT AdhityaAndrebina Agung, Jakarta, 2004.

Anshary, Hukum Waris Islam Dalam Teori dan Praktik, Pustaka Belajar, Yogyakarta, 2013, p. 87, quote from Eko Setiawan, Penerapan Wasiat Wajibah Menurut Kompilasi Hukum Islam (KHI) Dalam Kajian Normatif Yuridis, Muslim Heritage, Vol. 1, No. 2, 2016.

Fahmi Amruzi, Rekonstruksi Wasiat Wajibah dalam Kompilasi Hukum Islam, Aswaja Pressindo, Yogyakarta, 2014, p. 77, quoted from Eko Setiawan, Penerapan Wasiat Wajibah Menurut Kompilasi Hukum Islam (KHI) Dalam Kajian Normatif Yuridis, Muslim Heritage, Vol. 1, No. 2, 2016, p. 45.

Gunawan Widjaja, Alternatif Penyelesaian Sengketa, PT Raja Grafindo Persada, Jakarta, 2002.

Husain Musa Raghib, Mausu'ah Al-Iqtishad al-Islami fil-Masharif wan-Nuqud walAswaq al-Maliyah,Daras-Salam, Cairo, 2009.

Translate of Web, Surat Al-Hujurat Verse 9, accessed on 5 June 2020 from:https://tafsirq.com/49-alhujurat/ayat-9

WirjonoProdjodikoro, Hukum Warisan di Indonesia, Sumur Bandung, Bandung, 1991.

Web Translate of Surat An-Nisa Verse 7, accessed on January 28, 2020 from https://tafsirweb.com/1540-surat-annisa-ayat-7.html 
